\title{
Twice Dead
}




\section{CALIFORNIA SERIES IN PUBLIC ANTHROPOLOGY}

The California Series in Public Anthropology emphasizes the anthropologist's role as an engaged intellectual. It continues anthropology's commitment to being an ethnographic witness, to describing, in human terms, how life is lived beyond the borders of many readers' experiences. But it also adds a commitment, through ethnography, to reframing the terms of public debate-transforming received, accepted understandings of social issues with new insights, new framings.

\section{Series Editor: Robert Borofsky (Hawaii Pacific)}

Contributing Editors: Nancy Scheper-Hughes (UC Berkeley), Philippe Bourgois (UC San Francisco), and Arturo Escobar (University of North Carolina) University of California Press Editor: Naomi Schneider

I. Twice Dead: Organ Transplants and the Reinvention of Death, by Margaret Lock 


\section{Twice Dead}

Organ Transplants and the Reinvention of Death

\section{Margaret Lock}


University of California Press

Berkeley and Los Angeles, California

University of California Press, Ltd.

London, England

(C) 2002 by the Regents of the University of California

Grateful acknowledgment is made for permission to quote from Richard Selzer's Raising the Dead: A Doctor's Encounter with His Own Mortality (New York: Viking, I993); letters by Thomas J. Poulton and Gregory Liptak in Journal of the American Medical Association 255 (April I 8, I986): 2028, copyrighted I986, American Medical Association; and Mark Kennedy's "Brain Dead Donors 'Alive': MDs Debate Ethics of Transplant," Ottawa Citizen, March 3, I999.

Library of Congress Cataloging-in-Publication Data

Lock, Margaret M.

Twice dead : organ transplants and the reinvention of death / by Margaret Lock.

p. cm. - (California series in public anthropology; I)

Includes bibliographical references and index.

ISBN 0-520-22605-4 - ISBN 0-520-228I4-6

I. Transplantation of organs, tissues, etc.-Japan. 2.

Transplantation of organs, tissues, etc.-North America. 3. Brain death-Japan. 4. Brain death-North America. I. Title. II. Series. QP89.L63 2002

$617.9^{\prime} 5^{\prime} 0952-\mathrm{dc} 2 \mathrm{I}$

2001004 IIO

Printed in the United States of America

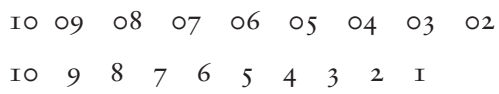

The paper used in this publication meets the minimum requirements of American National Standard for Information Sciences Permanence of Paper for Printed Library Materials, ANSI Z39.48-I984. 
To the memory of Nakawaga Yonezō 
This page intentionally left blank 